\title{
Pengembangan Key Resources dan Key Partnership dalam Aktivitas Bisnis Industri Kreatif UKM Garuda Jaya Malang
}

\author{
The Development of Key Resources and Key Partnership in the Business Activities \\ of Smes Creative Industry, Garuda Jaya Malang
}

\author{
Rizky Dwi R. P. H, Liana Parquinda, Lisa Purwanti, Mawar Farida, \\ Nia Mardiana dan Taufik Hidayat \\ Research Study Club, Fakultas Ilmu Administrasi Universitas Brawijaya
}

DOI:https://doi.org/10.32781/cakrawala.v12i1.268

Received : 27 Januari 2018

Accepted : 9 Mei 2018

Published : 21 Mei 2018

\begin{abstract}
Abstrak:
Penelitian ini bertujuan untuk mengetahui dan mendeskripsikan pengembangan key resources dan key partnership di UKM Garuda Jaya Kota Malang. UKM Garuda Jaya merupakan salah satu industri kreatif yang ada di Kota Malang yang memproduksi barang-barang yang berasal dari limbah yang pada awalnya merupakan limbah yang tidak bernilai guna menjadi barang yang bernilai guna. Penelitian ini menggunakan jenis penelitian deskriptif dengan pendekatan kualitatif. Metode pengumpulan data yang digunakan dalam penelitian ini adalah metode pengamatan, wawancara dan dokumentasi. Sedangkan metode analisis data dalam penelitian ini menggunakan teknik analisis data model interaktif Miles dan Huberman. Hasil penelitian menunjukkan bahwakey resources yang diterapkan UKM Garuda Jaya dapat dikatakan unik dikarenakan proses perekrutan karyawan dilakukan pada saat UKM Garuda Jaya melakukan kegiatan pelatihan. Hal ini dikarenakan UKM Garuda Jaya ingin menjaga kualitas produk yang diciptakan. Selain pengembangan key reesources, pengembangan key partnership juga dilakukan oleh UKM Garuda Jaya. Dalam memasarkan produknya, UKM Garuda Jaya memasarkan produknya sendiri baik di dalam maupun di luar negri dan juga menjalin kerjasama dengan mengikuti bazarbazar yang diadakan oleh Dinas Koperasi maupun Menteri Koperasi dan UMKM.
\end{abstract}

Kata kunci: Key Resources, Key Partnership, UKM GarudaJaya

\begin{abstract}
:
This research aims to find out and describe the development of key resources and key partnerships in UKM Garuda Jaya in Malang City. UKM Garuda Jaya is one of the creative industries in Malang City which produces goods that come from waste which initially are worthless waste to become useful items. This research uses descriptive research with a qualitative approach. Data collection methods used in this study are methods of observation, interviews and documentation. While the method of data analysis in this research uses Miles and Huberman interactive model data analysis techniques. The results show that the resources that are implemented by UKM Garuda Jaya can be said to be unique because the employee recruitment process is carried out when the UKM Garuda Jaya conducts training activities. This is because UKM Garuda Jaya want to maintain the quality of the products created. In addition to developing key resources, the development of key partnerships is also carried out by UKM Garuda Jaya. In marketing its products, UKM Garuda Jaya market their own products both inside and outside the country and also establish cooperation by participating in bazaars held by the Department of Cooperatives and the Minister of Cooperatives and UMKM.
\end{abstract}

Keywords: Key Resources, Key Partnership, UKM Garuda Jaya

How to Cite:

Rizky Dwi R. P. H, Liana Parquinda, Lisa Purwanti, Mawar Farida, Nia Mardiana dan Taufik Hidayat (2018). Pengembangan Key Resources dan Key Partnership dalam Aktivitas Bisnis Industri Kreatif UKM Garuda Jaya Malang. Cakrawala, 12(1), 107-117.

\footnotetext{
* Corresponding Author:

Nama : Rizky Dwi R. P. H

Email : herlambangluis1@gmail.com

Contact
}

두 2018 Badan Penelitian dan Pengembangan Provinsi Jawa Timur p-ISSN 1978-0354 | e-ISSN 2622-013X 


\section{Pendahuluan}

Usaha Kecil dan Menengah (UKM) memiliki peranan penting dalam perekonomian Indonesia, karena dengan adanya UKM ini, pengangguran akibat angkatan kerja yang tidak terserap dalam dunia kerja menjadi berkurang. Pemerintah Indonesia melalui berbagai kebijakan ekonomi. Hal ini dapat dilihat dari data Kementerian Koperasi dan Usaha Kecil Menengah (Kemenkop UKM) per Desember 2015 tercatat jumlah total koperasi di Indonesia sebanyak 212.135. Jumlah ini mencatatkan Indonesia sebagai negara dengan jumlah koperasi terbesar di dunia. Jumlah total koperasi tersebut terbagi atas 150.223 koperasi aktif dan 61.912 unit koperasi tidak aktif. Angka Produk Domestik Bruto (PDB) koperasi Indonesia terhadap negara sebesar 1,7\%. (http://www.kopnus.com, 2016).

Salah satu kota di Indonesia yang menyumbang pertumbuhan ekonomi di Indonesia adalah Kota Malang. Berdasarkan data Dinas Koperasi, Usaha Mikro, Kecil, dan Menengah Kabupaten Malang terdapat 227.791 UKM dengan penyerapan tenaga kerja 464.974 orang dan omset yang mencapai $\mathrm{Rp}$ 26.083.852.087.000 yang bergerak pada sektor perdagangan, pertanian, perkebunan, industri, aneka usaha dan jasa (dinkop.malangkota.go.id, 2014). Diantara UKM yang ada di Kota Malang Dinas Koperasi, Usaha Mikro, Kecil, dan Menengah Kota Malang mengelompokkan koperasi dan UKM unggulan di Kota Malang seperti Yans Keramik, Star Collection, So Kressh, Pandan Galeria, NN Collection, Kripik Tempe Amel, Instant Dia, Garuda Jaya, Dsil Homemade, Graping, Bennete Art Shop, Glass Painting Lita Decorative, Rizky Barokah, Wayang Soesmadi, dan Zahra Mandiri (Dinas Koperasi, Usaha Mikro, Kecil dan Menengah Kabupaten Malang, 2014).

Usaha Kecil dan Menengah (UKM) bidang industri kreatif yang menjadi unggulan di Kota Malang salah satunya adalah UKM Garuda Jaya. UKM Garuda Jaya bergerak di bidang industri kreatif. UKM Garuda Jaya ini menawarkan berbagai macam kerajinan tangan yang semuanya berasal dari bahan bekas yang didaur ulang. UKM Garuda Jaya merupakan salah satu UKM yang tidak hanya berfokus pada profit namun juga fokus kepada pemberdayaan masyarakat. UKM Garuda Jaya rutin melakukan pelatihan kerajinan tangan secara gratis kepada masyarakat sekitar maupun masyarakat luar Kota Malang. UKM Garuda Jaya juga telah melakukan penjualan tidak hanya di dalam negeri tetapi juga di mancanegara seperti Spanyol, Thailand dan Singapura. UKM Garuda Jaya juga sering digunakan sebagai tempat studi banding UKMlainnya.

Proses pengolahan bahan baku mulai dari nol sampai jadi bahan siap untuk dijual semuanya dilakukan di tempat usaha UKM Garuda Jaya. Keunikan dan kekreatifitasan dari produk yang ditawarkan oleh UKM Garuda Jaya ini membuat usahanya semakin berkembang dan semakin diminati oleh konsumen baik itu konsumen dalam negeri dan mancanegara. Faktor kesuksesan pemasaran produk yang ditawarkan oleh UKM Garuda Jaya sesuai dengan teori key resources dan key partership pada Business Model Canvas. Menurut Osterwalder dan Pigneur (2010, hal 34) key resources didefinisikan sebagai sumber daya utama yang menggambarkan aset-aset terpenting yang diperlukan agar sebuah model bisnis dapat berfungsi. Sumber daya ini memungkinkan perusahaan menciptakan dan menawarkan proposisinilai, menjangkau pasar, mempertahankan hubungan dengan segmen pelanggan, dan memperoleh pendapatan. Sumber daya utama dapat berbentuk fisik, finansial, intelektual, atau manusia. Key resources dalam UKM Garuda Jaya meliputi sumber daya fisik, dan sumber daya manusia. Sumber daya fisik UKM Garuda Jaya berupa bangunan, kendaraan, mesin, dan bahan baku. Bahan baku didapatkan dari para pemasok di desa-desa yang berupa klobot jagung, karet sandal, pelepah pisang, daun lamtoro, kain flanel, dan koran bekas. Pengolahan bahan baku sampai menjadi bahan setengah jadi dilakukan di tempat produksi UKM Garuda Jaya. Selain digunakan untuk proses produksi, UKM Garuda Jaya juga menjual bahan setengah jadi. Sedangkan sumber daya manusia UKM Garuda Jaya dari peserta pelatihan 3 besar dengan hasil yang terbaik dan akan direkrut langsung oleh UKM Garuda Jaya sebagai karyawan. Menurut Osterwalder dan Pigneur (2010, hal 38) key partnershipmenggambarkan jaringan pemasok dan mitra yang membuat model bisnis dapat bekerja. Key partnership UKM Garuda Jaya adalah Kementerian Koperasi dan Usaha Kecil dan Menengah, dan pemasok bahan baku yang dibutuhkan oleh UKM Garuda Jaya.

Peneliti tertarik dengan key resources karena pada UKM ini ada yang unik dalam perekrutan 
dan pengelolaan Sumber Daya Manusia (SDM), dan peneliti ingin mengetahui UKM Garuda Jaya menjalin hubungan kerjasama dengan siapa saja melalui key partnership. Key resources dan key partnership pada UKM Garuda Jaya dianggap penting karena analisis key resources dan key partnership berfungsi sebagai dasar untuk menciptakan dan menawarkan proposi nilai, menjangkau pasar, mempertahankan hubungan dengan segmen pelanggan, dan memperoleh pendapatan, serta untuk memperkuat posisi UKM Garuda Jaya. Berdasarkan uraian tersebut maka peneliti tertarik untuk melakukan penelitian dengan judul "Pengembangan Key Resources dan Key Partnership dalam Aktivitas Bisnis pada Industri Kreatif UKM Garuda Jaya Malang."

\section{Tinjauan Pustaka}

\section{Industri Kreatif}

Industri kreatif merupakan industri yang sumber daya nya berasal dari intelektual manusia. Industri keratif adalah industri yang berasal dari pemanfaatan kreativitas, keterampilan serta bakat individu untuk menciptakan kesejahteraan dan lapangan pekerjaan dengan menghasilkan dan memberdayakan daya kreasi dan daya cipta individu tersebut Departemen Perdagangan RI (2009:5). "Industri kreatif yang mengandalkan talenta, ketrampilan, dan kreativitas yang merupakan elemen dasar setiap individu Simatupang (2007). Unsur utama industri kreatif adalah kreativitas, keahlian, dan talenta yang berpotensi meningkatkan kesejahteraan melalui kesejahteraan melalui penawaran kreasi intelektual".

UNCTAD dan UNDP dalam Creative Economy Report (2008:4) menjelaskan bahwa "Industri kreatif dapat didefinisikan sebagai siklus kreasi, produksi, serta distribusi barang dan jasa yang menggunakan kreativitas dan modal intelektual sebagai input utama. Industri kreatif terdiri dari seperangkat pengetahuan berbasis aktivitas yang menghasilkan barangbarang riil dan intelektual nonriil atau jasa- jasa artistik yang memiliki kandungan kreatif tersusun dari suatu bidang yang heterogen yang saling mempengaruhi dari kegiatan- kegiatan kreatif yang bervariasi, yang tersusun dari seni dan kerajinan tradisional, penerbitan, musik, visual dan pembentukan seni sampai dengan penggunaan teknologi yang intensif dan jasajasa yang berbasis kelompok, seperti film, televisi, dan siaran radio, serta media baru dan desain". Industri kreatif bermodalkan kreatif dan inovatif dalam suatu aktivitas sehingga menghasilkan barang dan jasa yang dapat memenuhi kebutuhan manusia yang heterogen. Kegiatan dalam industri kreatif meliputi proses produksi barang baru atau barang yang sudah ada sebelumnya akan tetapi diberikan sedikit tambahan inovasi agar lebih bermanfaat.

\section{Bisnis Model Kanvas}

Bisnis model kanvas memberikan gambaran mengenai konsep bisnis perusahaan. Menurut Alexander Osterwalder dan Yves Pigneur (2010, 14-15) menjelasan bahwa sebuah model bisnis menggambarkan dasar pemikiran tentang bagaimana organisasi menciptakan, memberikan dan menangkap nilai. Setiap nine basic buliding blocks, dapat menjadi langkah awal untuk menentukan darimana suatu perusahaan melakukan transformasi bisnis model mereka. Untuk menjawab tantangan sebuah perusahaan dalam penyelesaian permasalahannya, maka dibutuhkan pemetaan terhadap berbagi aspek seperti nilai jual yang ditawaran oleh perusahaan, segementasi pasar konsumen perusahaan, proses bisnis yang sedang dijalani, cara mempertahankan hubungan dengan pelanggan, aktivitas yang dijalanan oleh perusahaan, distribusi yang dijalankan perusahaan, mengelola sumber daya yang dimiliki perusahaan, biaya yang dikeluaran oleh perusahaan, penerimaan yang diperoleh perusahaan, bentuk kerjasama dengan pihak pihak luar perusahaan yang membantu dalam kegiatan perusahaan. Nine building blocks tersebut yaitu: value propotitions, customer segment, customer relationship, channels, key resource, key activities, key partnership, cost structure, dan revenue stream.

Value propotitions, menurut Osterwalder dan Pigneur (2010: 22) value propotition didefinisikan sebagai kumpulan produk dan jasa yang memberikan nilai untuk segmen pelanggan yang spesifik. Value propotition merupakan alasan utama kenapa customer bertahan kepada sebuah produk atau bahkan pindah ke produk lainnya.

Customer Segment, menurut Osterwalder dan Pigneur (2010: 20) customer segment didefinisikan sebagai kelompok orang atau 
organisasi yang berbeda-beda yang ditargetkan untuk dicapai dan dilayani oleh suatu perusahaan.

Customer Relationship, menurut Osterwalder dan Pigneur (2010: 28) customer relationship adalah jenis relasi yang ditentukan perusahaan dengan segmen pelanggan yang spesifik. Motivasi dibalik hubungan dengan pelanggan ini antara lain untuk akuisisi dan retensi pelanggan bahkan untuk meningkatkan penjualan.

Channels, menurut Osterwalder dan Pigneur (2010: 26) channels adalah bagaimana perusahaan berkomunikasi dengan dan menjangkau segmen pelanggan mereka untuk menyampaikan value propotition perusahaan.

Cost Structure, menurut Osterwalder dan Pigneur (2010:40) cost structure merupakan semua biaya yang muncul untuk mengoperasikan bisnis model.

Revenue Stream, menurut Osterwalder dan Pigneur (2010:30) revenue stream didefinisikan sebagai kemampuan perusahaan dalam menghasilkan uang dari setiap customer segment.

Key Activities, menurut Osterwalder dan Pigneur (2010:37) key activities yaitu tindakantindakan terpenting yang harus diambil perusahaan agar dapat beroperasi dengan sukses

Key Resource, menurut Osterwalder dan Pigneur (2010:35) key resource didefinisikan sumber daya yang memungkinkan perusahaan menciptakan dan menawarkan proposi nilai, menjangkau pasar, mempertahankan hubungan dengan segmen pelanggan, dan memperoleh pendapatan.

a. Fasilitas (Physical)

Dalam kategori ini termasuk aset-aset fisik misalnya fasilitas pabrik, bangunan, mesin dan peralatan, sistem, sistem penjualan, dan jaringan distribusi.

b. Intelektual (Intellectual)

Sumber daya intelektual meliputi brands, pengetahuan yang dilindungi, paten dan hak cipta, partnerships, dan database pelanggan yang merupakan komponen yang penting dalam membuat model bisnis yang kuat. Sumber daya intelektual sangat sulit untuk dibangun namun saat telah berhasil dibangun dapat memberikan nilai tambah yang sangat bagus.

c. Manusia (Human)

Setiap bisnis memerlukan sumber daya manusia, namun manusia adalah aset yang sangat penting dalam model bisnis.

d. Finansial (Financial)

Beberapa model bisnis membutuhkan sumberdaya finansial dan atau jaminan finansial, misalnya uang tunai, kredit, kebutuhan-kebutuhan lain untuk memenuhi kebutuhan sumberdaya perusahaan.

e. Teknologi (Technology)

Pada perusahaan yang high-tech, teknologi menjadi sumber daya utama yang sangat menentukan. Pada perusahaan telekomunikasi, penguasaan teknologi terbaru menjadi penentu untuk mewujudkan value propositions yang dijanjikan kepada pelanggan.

f. Saluran Distribusi (Channel)

Saluran distribusi kini juga menjadi sumber daya yang penting. Bagi perusahaan consumer good, saluran distribusi untuk produk mereka menjadi sangat penting (Osterwalder dan Pigneur, 2010, hal: 35)

Key Partnership, menurut Thomson dalam Osterwalder dan Pigneur (2010), partnership merupakan perjanjian formal diantara dua atau lebih perusahaan terpisah dimana di dalamnya terdapat kesepakatan dan kerjasama dalam mengembangkan dan memperkuat posisi suatu perusahaan. Ada empat jenis kemitraan yaitu:

a. Strategi aliansi antara non-pesaing.

b. Strategi kemitraan antara pesaing (Coopetition).

c. Usaha bersama: usaha untuk mengembangkan bisnis baru.

d. Hubungan Pembeli-Pemasok untuk menjamin pasokan yang dapat diandalkan. (Osterwalder dan Pigneur, 2010:38)

\section{Metode Penelitian}

\section{Jenis Penelitian}

Jenis penelitian yang digunakan adalah deskriptif. Penelitian deskriptif bertujuan untuk menggambarkan keadaan suatu fenomena, dalam penelitian ini tidak dimaksudkan untuk menguji hipotesis tertentu tetapi hanya menggambarkan apa adanya suatu variabel, gejala atau kejadian (Arikunto, 2002).

Penelitian ini menggunakan pendekatan kualitatif. Menurut Denzin dan Linclon (dalam Moleong, 2012), jenis penelitian kualitatif adalah penelitian yang menggunakan latar ilmiah, dengan maksud menafsirkan fenomena yang terjadi dan dilakukan dengan jalan melibatkan berbagai metode yang ada. Pendekatan kualitatif 
akan mempermudah peneliti dalam hal menggali dan menafsirkan suatu fenomena yang berkaitan dengan Key Resource dan Key Partnership pada UKM Garuda Jaya.

\section{Lokasi dan Waktu Penelitian}

Lokasi penelitian adalah tempat peneliti mengungkapkan keadaan sebenarnya objek yang diteliti. Sedangkan situs penelitian merupakan letak sebenarnya peneliti mengadakan penelitian untuk mendapatkan data yang valid, akurat dan benar-benar dibutuhkan dalam penelitian. Adapun lokasi penelitian ini berada di Kota Malang. Sedangkan situs dari penelitian ini adalah UKM Garuda Jaya yang berada di Jl. Dirgantara II C No. 29 Malang.

Alasan pemilihan lokasi dan situs penelitian ini dikarenakan Garuda Jaya merupakan salah satu UKM yang ada di Kota Malang dan bergerak di industri kreatif. Selain itu, UKM Garuda Jaya juga memiliki produk yang unik dan inovatif.

\section{Fokus Penelitian}

MenurutSpradley dalamSugiyono(2012:208), fokus penelitian merupakan domain tunggal atau beberapa domain yang terkait dari situasi sosial. Dalam penelitian ini penulis ingin meneliti tentang Key Resource dan Key Partnership yang ditawarkan oleh Garuda Jaya dalam memenuhi kebutuhan konsumen. Fokus ini diturunkan dari teori business model canvas yang lebih spesifikkan kepada Key Resources dan Key Partnership. Fokus ini dipilih karena permasalahan terkait aspek pemenuhan kebutuhan konsumen Garuda Jaya menjadi permasalahan yang urgent untuk segera diselesaikan. Secara matematis fokus penelitian ini adalah:
a. Key Resource
1. Fasilitas (Physical)
2. Intelektual (Intellectual)
3. Manusia (Human)
4. Finansial (Financial)
5. Teknologi (Technology)
6. Saluran Distribusi (Channel)

b. Key Partnership

1. Strategi aliansi antara non-pesaing.

2. Strategi kemitraan antara pesaing (Coopetition).

3. Usaha bersama: usaha untuk mengembangkan bisnis baru.

4. Hubungan Pembeli-Pemasok untuk menjamin pasokan yang dapat diandalkan.

\section{Sumber Data}

Jenis sumber data yang digunakan dalam penelitian ini adalah:

1. Data Primer

Data primer adalah data yang diperoleh secara langsung dari orang- orang atau informan yang sengaja dipilih oleh peneliti untuk memperoleh data-data informasi yang ada relevansinya dengan permasalahan penelitian. Sumber data primer penelitian ini adalah wawancara dengan pendiri UKM Garuda Jaya dan para karyawan di UKM Garuda Jaya.

2. Data Sekunder

Menurut Silalahi (2009) data sekunder adalah data yang dikumpulkan melalui sumbersumber lain yang tersedia. Data sekunder penelitian ini antara lain dokumen-dokumen pendukung lainnya.

\section{Teknik Pengumpulan Data}

Pada penelitian kualitatif, pengumpulan data dilakukan pada natural setting (kondisi yang alamiah), sumber data primer, dan teknik pengumpulan data lebih banyak pada observasi berperan serta, wawancara mendalam, dan dokumentasi (Sugiyono, 2012: 225). Metode atau teknik tersebut dijelaskan sebagai berikut:

a) Pengamatan atau observasi yang dimaksud adalah pengamatan yang sistematis tentang kejadian dan tingkah laku dalam setting sosial yang dipilih untuk diteliti

b) Wawancara yang mendalam (in-depth interviews) adalah tenik pengumpulan data yang didasarkan pada percakapan secara intensif dengan suatu tujuan tertentu. Wawancara dilakukan untuk mendapat berbagai informasi menyangkut masalah yang diajukan dalam penelitian.

c) Dokumentasi

Selain observasi dan wawancara, data juga dikumpulkanmelalui dokumentasi. Dokumentasi adalah teknik pengumpulan data dengan menggunakan tulisan-tulisan sebagai bagian dari data seperti Kegiatan Proses Produksi dan lain-lain yang berhubungan dengan penelitian.

\section{Instrumen Penelitian}

Adapun instrumen penelitian ini adalah:

1. Peneliti, karena peneliti melakukan wawancara terhadap informan. 
2. Interview guide untuk tiap informan, pedoman observasi, pedoman dokumentasi, dan buku catatan lapangan digunakan untuk membatasi dan mengarahkan peneliti dalam mencari data-data yang diperlukan sesuai dengan fokus buku catatan lapangan dibuat oleh peneliti saat melakukan wawancara, pengamatan, maupun saat menyaksikan kejadian-kejadian tertentu.

3. Alat perekam, alat komunikasi, dan buku catatan digunakan saat melakukan observasi dan wawancara serta sebagai alat untuk pengumpulan data.

\section{Metode Analisis}

Penelitian ini menggunakan teknik analisis data model Miles dan Huberman. Menurut Miles dan Huberman (1984) dalam Sugiyono (2010) bahwa aktivitas dalam analisis data kualitatif dilakukan secara interaktif dan berlangsung secara terusmenerus sampai tuntas, sehingga datanya sudah jenuh. Aktivitas dalam analisis data, yaitu: data reduction, data display dan conclusion drawing/verification.

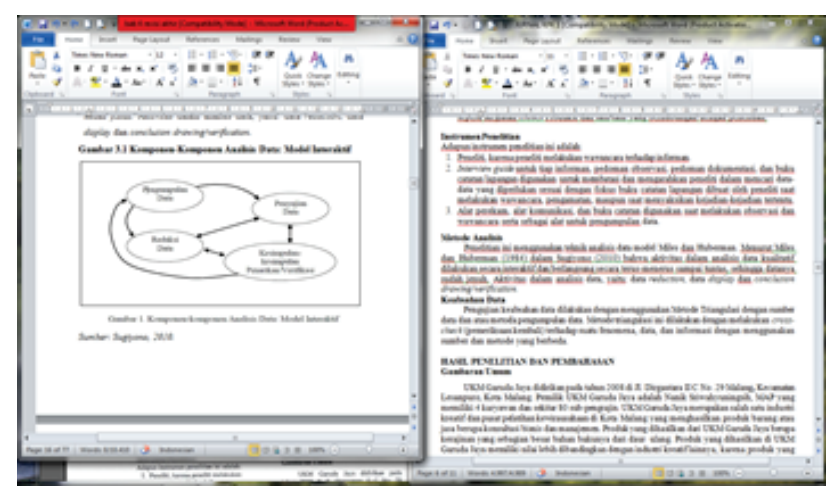

Sumber:Sugiyono, 2010.

Gambar 1 Komponen-komponen Analisis Data Model Interaktif

\section{Keabsahan Data}

Pengujian keabsahan data dilakukan dengan menggunakan Metode Triangulasi dengan sumber data dan atau metoda pengumpulan data. Metode triangulasi ini dilakukan dengan melakukan cross-check (pemeriksaan kembali) terhadap suatu fenomena, data, dan informasi dengan menggunakan sumber dan metode yang berbeda.

\section{Hasil dan Pembahasan}

\section{Gambaran Umum}

UKM Garuda Jaya didirikan pada tahun 2008 di Jl. Dirgantara II C No. 29 Malang, Kecamatan Lesanpuro, Kota Malang. PemilikUKM Garuda Jaya adalah Nanik Sriwahyuningsih, MAP yang memiliki 4 karyawan dan sekitar 80 subpengrajin. UKM Garuda Jaya merupakan salah satu industri kreatif dan pusat pelatihan kewirausahaan di Kota Malang yang menghasilkan produk barang atau jasa berupa konsultasi bisnis dan manajemen. Produk yang dihasilkan dari UKM Garuda Jaya berupa kerajinan yang sebagian besar bahan bakunya dari daur ulang. Produk yang dihasilkan di UKM Garuda Jaya memiliki nilai lebih dibandingkan dengan industri kreatif lainnya, karena produk yang dihasilkan dari bahan daur ulang dengan beragam inovasi yang unik.

Produk UKM Garuda Jaya sudah dikenal sebagian besar masyarakat Kota Malang khususnya. Pemilik UKM Garuda Jaya dipercaya oleh Disperindag Kota Malang untuk menjadi mentor dalam pelatihan kewirausahaan. Tim UKM Garuda Jaya juga sering mengadakan pameran-pameran, studi banding dan pelatihan di berbagai kota. Pelatihan kewirausahaan yang dilakukan oleh UKM Garuda Jaya adalah memberdayakan peserta sesuai dengan minatnya. Yang menarik adalah UKM Garuda Jaya melakukan pelatihan kewirausahaan tanpa memungut biaya, peserta pelatihan hanya mengganti biaya bahannya saja. Output dari pelatihan kewirausahaan oleh UKM Garuda Jaya adalah peserta dengan hasil karya terbaik akan dihubungi oleh UKM Garuda Jaya apabila ada order produk dari pelanggan.

\section{Penyajian Data}

1. Key Resource

Key Resources menggambarkan asset-aset terpenting yang diperlukan agar sebuah model bisnis dapat berfungsi. Sumber daya ini memungkinkan perusahaan menciptakan dan menawarkan proposisi nilai, menjangkau pasar, mempertahankan hubungan dengan segmen pelanggan, dan memperoleh pendapatan. Kebutuhan sumber daya utama berbeda-beda sesuai jenis model bisnis. Adapun sumber daya utama dapat dikategorikan sebagai berikut: 
a) Fasilitas (Physical)

Fasilitas adalah segala sesuatu yang dapat mempermudah upaya dan memperlancar kerja dalam rangka mencapai tujuan. UKM Garuda Jaya memiliki beberapa fasilitas untuk menunjang kegiatan usahanya. UKM Garuda Jaya memiliki beberapa fasilitas seperti mobil, mesin dan tempat yang luas untuk melaksanakan pelatihan kerajinan tangan yang dilakukan pada setiap hari Sabtu. Salah satu fasilitas yang sering digunakan untuk kegiatan produksi UKM Garuda Jaya adalah mesin. Mesin yang dimiliki UKM Garuda Jaya terdapat di rumah produksi, selain itu mesin mesin juga tersebar di sub-pengrajin UKM Garuda Jaya, dan juga ada beberapa mesin yang disumbang dari Dikti. Mesin yang dimiliki oleh UKM Garuda Jaya yaitu mesin untuk produksi klobotjagung dan mobil digunakan untuk mengambil dan mengantar barang pesanan. Fasilitas tersebut sangat membantu dalam kegiatan usaha di UKM Garuda Jaya. Fasilitas yang dimiliki oleh UKM Garuda Jaya masih dalam kondisi baik.

b) Intelektual (Intellectual)

Sisi intelektualitas UKM Garuda Jaya dapat dilihat dari segi ketenaran atau diketahuinya UKM Garuda Jaya oleh masyarakat. UKM Garuda Jaya sudah banyak diketahui oleh masyarakat luas baik dari dalam negeri maupun luar negeri, hal tersebut dikarenakan UKM Garuda Jaya sering melakukan pameran di dalam negeri maupun luar negeri, selain itu UKM Garuda Jaya juga sudah memiliki surat izin untuk mendirikan usaha di dalam negeri dan juga sudah mempunyai Hak Paten dan Hak Cipta atas barang yang mereka produksi.

c) Manusia(Human)

SaatiniUKMGaruda Jaya memilikikurang lebih 80 pengarajin (UKM Garuda Jaya menyebut karyawan sebagai Pengrajin) untuk menunjang produksi atas pesanan dari pelanggan. Para pengrajin di UKM Garuda Jaya memiliki kualitas yang baik, dikarenakan tidak semua orang dapat membuat kerajinan handmade. Penilaian rekruitmen di UKM Garuda
Jaya berdasarkan kemampuan dan inovasi dalam mendesain produk yang diajarkan selama pelatihan kerajinan melalui sistem ranking. UKM Garuda Jaya melakukan inovasi terhadap 14 item produknya melalui pelatihan khusus yang diberikan kepada para pengrajin. Hal tersebut dilakukan untuk mengembangkan produk dan meningkatkan kulitas para pengrajinnya.

d) Keuangan(Financial)

Jadi, dalam sisi keuangan, UKM Garuda Jaya tidak terlalu memerlukan dana yang bersar. Hal ini dikarenakan UKM Garuda Jaya mayoritas bahan baku berasal dari barang bekas atau limbah. Sumber modal UKM Garuda Jaya berasal dari penjualan dan dana dari instansi pemerintah dan dari instansi pendidikan. Namun, UKM Garuda Jaya masih belum menerapkan sistem informasi untuk melakukan pencatatan pemasukan maupun pengeluaran. Pencatatan keuangan secara tersistem akan memudahkan pengelolaan UKM Garuda Jaya dan untuk efisiensi waktu.

e) Teknologi (Technology) Jadi, dapat disimpulkan bahwa penggunaan teknologi baik itu teknologi dalam pembuatan produk dan teknologi dalam hal memasarkan produk masih sangat minim. Pada proses pembuatan produk kerajinan tangan para pengarajin memang tidak menggunakan teknologi mesin, hal ini dikarenakan UKM Garuda Jaya merupakan salah satu UKM yang berfokus pada handmade, sedangkan pada proses pemasaran produk kerajinan tangan, UKM Garuda Jaya tidak melayani pembelian ataupun pemesanan secara online, dikarenakan terbatasnya SDM yang ada untuk memenuhi pesanan.

f) Saluran Distribusi (Channel)

UKM Garuda Jaya dalam proses distribusi tergantung pemesanan dari pelanggannya, apabila terdapat pelanggan yang memesan produk dari Koran, maka pihak UKM akan mengontak pengrajinnya untuk mengerjakan pemesanan dari pelanggan tersebut, setelah selesai produk tersebut akan dikirim ke UKM Garuda Jaya. 
Apabila pihak UKM Garuda Jaya sibuk maka pelanggan akan mengambil sendiri pesanannya atau sebaliknya.

2. Key Partnership

Key Partnership adalah Kunci Kemitraan yang menjelaskan jaringan pemasok dan mitra yang membuat pekerjaan model bisnis. Perusahaan menjalin kemitraan untuk banyak alasan, dan kemitraan menjadi landasan model bisnis. Perusahaan membentuk aliansi untuk mengoptimalkan model bisnisnya, mengurangi resiko, atau memperoleh sumber daya.

a) Strategi hubungan kerjasama antara non pesaing

UKM Garuda Jaya juga menjalin hubungan kerjasama dengan perusahaan lain. Kerjasama yang telah dilakukan selama ini telah berjalan dengan baik. UKM Garuda Jaya melakukan kerjasama dengan menerapkan saluran network. Cara UKM Garuda Jaya menjalin kerjasama dengan perusahaan lain yaitu dengan melakukan pelatihanpelatihan mengenai kerajinan tangan dan juga menjadi pembicara pada acara seminar-seminar misalnya di koperasi-koperasi wanita, sekolah-sekolah maupun pelatihan terbuka yang diadakan oleh UKM Garuda Jaya. Dengan diadakannya kegiatan tersebut, maka akan semakin memperluas jaringan kerjasama UKM Garuda Jaya baik itu kerjasama dalam memasok bahan baku maupun kerjasama dalam hal tenaga kerja atau pengrajin. Kerjasama yang dilakukan oleh UKM Garuda Jaya dengan perusahaan lain tidak dilakukan hanya untuk menguntungkan salah satu pihak saja tetapi saling menguntungkan antara kedua belah pihak.

b) Strategi kemitraan antara pesaing (Coopetition)

Strategi kemitraan antara pesaing (coopetition) yang dilakukan oleh UKM garuda Jaya, tergantung permintaan peserta pelatihan, sehingga pelatihan yang dilakukan oleh UKM garuda Jaya tidak sama antara peserta yang satu dengan peserta yang lainnya. Pelatihan yang dilakukan UKM Garuda Jaya bersifat gratis, para peserta pelatihan hanya membayar bahan yang dibutuhkan dalam pelatihan, sedangkan ilmu dasar setiap kerajinan yang diberikan oleh sang pelatih diberikan secara gratis atau cuma-cuma.

c) Usaha bersama: usaha untuk mengembangkan bisnis baru

UKM Garuda Jaya tidak melakukan usaha kerjasama dengan perusahaan lain, sehingga usaha bersama yang dilakukan oleh UKM Garuda Jaya dalam hal mengembangkann bisnis baru tidak ada. Namun, UKM Garuda Jaya telah melakukan kerjasama dengan Dinas Koperasi dan UMKM Kota Malang. UKM Garuda Jaya menjalin kerjasama dengan peserta pelatihan atau yang biasa disebut dengan sub pengrajin yang tersebar di Indonesia, selain itu UKM Garuda jaya telah menerima kontrak kerjasama dengan dinas untuk melakukan pelatihan kewiraushaan namun untuk kerjasama dengan UKM lain tidak dilakukan oleh UKM Garuda Jaya

d) Hubungan Pembeli - Pemasok untuk menjamin pasokan yang dapat diandalkan

Bahan baku yang dibutuhkan oleh UKMGaruda Jaya sangat bermacam dan bervariasi karena produk yang dihasilkan juga terdiri dari berbagai macam jenis kerajinan. Untuk kebutuhan pemasok bahan baku tergantung dengan jenis bahan baku. Bahan baku yang bersifat alami biasanya bekerjasama dengan pemasok yang berada dari desa, karena pemasok memiliki bahan baku yang berlimpah dan belum dimanfaatkan secara maksimal. Bahan baku yang diperoleh dari pemasok desa biasanya dihubungi satu bulan sebelumnya untuk 
pemesanan oleh UKM Garuda Jaya dengan menerapkan standar tertentu. Sedangkan bahan baku yang bersifat non alami atau non limbah, UKM Garuda Jaya langsung membeli di toko yang menyediakan bahan baku tersebut. UKM garuda Jaya menjain hubungan kerjasama dengan pemasok untuk mendapatkan bahan baku dilakukan pemesanan jauh jauh hari kepada pemasok dengan melakukan telepon terlebih dahulu. Hal tersebut dialkukan untuk mengantisipasi musim yang tidak pasti, seperti pelepah pisang yang jarang ditemui atau sulit ditemui pada saat musim hujan. Oleh karena itu, untuk pihak UKM Garuda Jaya melakukan persediaan bahan baku yang lumayan besar didalam rumah pelatihan yang berada di jalan dirgantara IIC No. 2 .

\section{Simpulan}

Sumber daya yang dimiliki oleh UKM Garuda Jaya diantara lain adalah mesin-mesin yang menunjang efisiensi produksi, Sumber Daya Manusia yang mempengaruhi kualitas produk, dana dan sistem pencatatan demi menunjang keberlangsungan usaha, penggunaan teknologi informasi demi memperlancar pekerjaan dan channel untuk memperlancar pendistribusian produk, key resources yang diterapkan pada industri kreatif Usaha Kecil dan Menengah Garuda Jaya Kota Malang meliputi, fasilitas, intelektual, manusia, keuangan, teknologi, dan saluran distribusi. Fasilitas yang tersedia di UKM Garuda Jaya untuk menunjang kegiatan usaha dapat dikatakan cukup lengkap, mesin dan peralatan yang dimiliki juga dalam kondisi yang baik. Intelektual yang dimiliki oleh UKM Garuda Jaya dapat dikategorikan cukup baik, dikarenakan merek atau brand UKM Garuda Jaya sudah terkenal di lingkungan domestik maupun mancanegara. UKM Garuda Jaya selalu melakukan inovasi-inovasi produk guna menarik hati pelanggan, UKM ini memiliki cara yang unik dalam menjaga dan meningkatkan ketrampilan karyawannya. Produk handmade yang dihasilkan oleh UKM Garuda Jaya sudah cukup dikenal oleh masyarakat domestik maupun mancanegara, misalnya di Singapura.
Hal tersebut tentunya tidak terlepas dari kualitas sumber daya manusia yang dimiliki oleh UKM Garuda Jaya. Manusia merupakan salah satu elemen key resources. Proses perekrutan karyawan di UKM Garuda Jaya tergolong berbeda dengan perusahaan lainnya, karena kualitas sumber daya manusia di UKM Garuda Jaya harus memenuhi kompetensi pelatihan ketrampilan. Dari segi keuangan, sumber dana yang didapatkan oleh UKM Garuda Jaya sebagian besar berasal dari modal mandiri dikarenakan bahan baku yang digunakan kebanyakan berasal dari limbah. Selain itu, UKM Garuda Jaya juga mendapat dana bantuan dari Dinas Koperasi dan UMKM. Pada perusahaan teknologi merupakan elemen pendukung dalam proses produksi, pemesanan, dan pemasaran. Penggunaan teknologi dalam proses produksi di UKM Garuda Jaya tergolong terbatas, dikarenakan produk yang dihasilkan kebanyakan dari handmade, dalam pemesanan produk di UKM Garuda Jaya masih menggunakan jaringan telepon selular, sedangkan dalam proses pemasaran masih mengandalkan pada bazaar dan pameranpameran. Saluran distribusi merupakan alat dalam penyaluran produk dari perusahaan ke pelanggan. Proses distribusi produk yang diterapkan UKM Garuda Jaya yaitu sistem network, dimana produk di promosikan secara langsung atau rekomendasi dari konsumen lain serta UKM Garuda Jaya juga mengikuti bazarbazar yang diadakan oleh Dinas Koperasi maupun Menteri Koperasi dan UMKM. Pada saat UKM Garuda Jaya mengikuti sebuah pameran maupun bazaar, UKM Garuda Jaya akan memajang produk-produk kerajinan tangan namun produk tersebut hanya sebuah contoh saja, jika ada pelanggan yang ingin membeli barang yang sama seperti display atau contoh produk tersebut harus memesan dulu dengan menghubungi kontak yang berada di kartu nama atau banner yang terpasang. Key partnership sangat membantu dalam kegiatan bisnis dan keberlangsungan usaha UKM Garuda Jaya. UKM Garuda Jaya menjalin hubungan kerjasama dengan pemasok, Dinas Koperasi dan UMKM sebagai fasilitator pelatihan kewirausahaan, Disperindag, Kementerian Koperasi dan UMKM sebagai peminjam dana, serta Universitas Brawijaya sebagai Corporate Social Responsibility (CSR). UKM Garuda Jaya 
melakukan kerjasama dengan menerapkan kerjasama secara network. Cara UKM Garuda Jaya menjalin kerjasama dengan perusahaan lain yaitu dengan melakukan pelatihan-pelatihan mengenai kerajinan tangan dan juga menjadi pembicara pada acara seminar-seminar misalnya di koperasi-koperasi wanita, sekolah-sekolah maupun pelatihan terbuka yang diadakan oleh UKM Garuda Jaya.

\section{Saran}

Adapun saran yang diberikan oleh peneliti adalah sebagai berikut: (1) Dalam mengatasi kekurangan jumlah Sumber Daya Manusia, UKM Garuda Jaya sebaiknya lebih merutinkan pelatihanpelatihan kewirausahaan guna mendapatkan Sumber Daya Manusia yang berkualitas. (2) Membuat pencatatan keuangan dengan meggunakan Sistem Informasi agar data dapat disajikan secara tepat waktu dan akurat bagi UKM Garuda Jaya serta memperbaiki pencatatan keuangan yang sebelumnya bersifat tradisional menjadi lebih efektif dan efisien (3) Memanfaatkan teknologi yang sudah ada baik dalam proses produksi maupun proses pemasaran. Misalnya, menggunakan membuat website yang memuat tentang produk-produk yang dihasilkan UKM Garuda Jaya agar lebih dikenal oleh masyarakat serta melakukan pemasaran secara online melalui website tersebut. (4) Melakukan inovasi terhadap produk-produk yang selama ini dihasilkan oleh UKM Garuda Jaya, seperti produk yang mengikuti trend pasar, melakukan inovasi produk, pengembangan unit bisnis, dan lainnya.

\section{Daftar Pustaka}

Arikunto, Suharsimi. 2002. Metodologi Penelitian. PT. Rineka Cipta.Jakarta.

Arikunto. 2005. Manajemen Penelitian. Rineka Cipta, Jakarta

Azis, Noor. 2007. Penerapan Sistem Informasi Pemasaran pada Usaha Kecil Menengah (UKM) di Kota Malang. [Online] diakses melalui http://directory.umm.ac.id/ pada tanggal 25 Mei 2016.
Dewobroto, Wisnu Sakti. 2013. Penggunaan Business Model Canvas sebagai Dasar untuk Menciptakan Alternatif Strategi Bisnis dan Kelayakan Usaha. [Online] diakses melalui http://blog.trisakti.ac.id/ jurnalti/files/2013/09/3 Penggunaa n-Business-Model-Canvas WisnuSakti-D.pdf. Diakses pada tanggal 9 Juni 2016.

Dinas Koperasi, Usaha Mikro, Kecil dan Menengah Kabupaten Malang. 2014. Kebijakan Program. [Online] diakses $\mathrm{m} \quad \mathrm{e} \quad \mathrm{l}$ a $\quad \mathrm{l}$ u $\mathrm{i}$ http://dinkop.malangkota.go.id/201 5/09/08/koperasi-dan-ukmunggulan-di-kota-malang/ pada tanggal 20 Mei 2016.

Frisdiantara dkk 2016.Ekonomi Pembangunan: Sebuah Kajian Teoritis dan Empiris. [Online] diakses melalui http://books.go.id pada tanggal 25 Mei 2016.

Hassan, Almoatazbillah. 2012. The Value Proposition Concept in Marketing: How Customers Perceive the Value Delivered by Firms. [Online] diakses melalui www.cosenet.org/ padatanggal26Mei2016

Hermawan, Aji dan Rachel Jessica Pravitasari. Business Model Canvas (Kanvas Model Bisnis). 2014. [Online] diakses melalui http://akselerasi.id/media/Materi_1 3 _ Business_Model_Canvas.pdf pada tanggal 9 Juni 2016. Diakses pada 10 Agustus 2016.

Menteri Koperasi dan Usaha Kecil dan Menengah. 2008. Undang-Undang Republik Indonesia Nomor 20 Tahun 2008 Tentang Usaha Mikro, Kecil, dan Menengah. Jakarta: Kementerian Koperasi dan Usaha Kecil dan Menengah.

Moleong, L.J. 2012. Metodologi Penelitian Kualitatif Edisi Revisi.Bandung: PT Remaja Rosdakarya. 
Noe, Raymond., Hollenbeck, John R., Gerhart B., Wright, Patrick M. 2010. Manajemen Sumber Daya Manusia (Mencapai Keunggulan Bersaing). Edisi 6. Buku 2. Alih Bahasa David Wijaya. Jakarta: Salemba Empat.

Osterwelder dkk, 2010. Business Model Generation. Amsterdam: www.modderman.nl. Diakses pada 12 Agustus 2016.

Sukardi, David dan Kurniawan Indonanjaya. 2010. Manajemen Investasi: Pendekatan Teknikal dan Fundamental untuk Analisis Saham. Yogyakarta: Graha Ilmu.

Silalahi, Ulber. 2009. Metode Penelitian Sosial. Bandung: PT. Refika Aditama.
Simatupang, Togar. 2007. Ekonomi Kreatif: Menuju Era Kompetisi dan Persaingan Usaha Ekonomi Gelombang IV. Institut $\mathrm{T}$ e k n o lo g i B a n d u n g. http://www.slideshare.net/togar/ce tak-biru-industri-kreatif-jabar. Diakses pada 12 Agustus 2016.

Sugiyono. 2010. Memahami Penelitian Kualitatif. Bandung: ALFABETA.

Sugiyono. 2012. Memahami Penelitian Kualitatif. Bandung: ALFABETA.

. 2008. "Pengembangan Ekonomi Kreatif Indonesia 2025". Departemen Perdagangan Republik Indonesia. Depdag.

UNDP/UNCTAD. 2008. Creative Economy, Reposrt 2008. Geneva-New York: UNDP, UNCTAD. 